\title{
Chemometric characterization of peach, nectarine and plum cultivars according to fruit phenolic content and antioxidant activity
}

\author{
Violeta Mitic ${ }^{\star}$, Marija Ilic, Marija Dimitrijevic, Jelena Cvetkovic, Slobodan Ciric \\ and Vesna Stankov Jovanovic
}

University of Niš, Faculty of Science and Mathematics, Department of Chemistry, Višegradska 33, 18000 Niš, Serbia

Received 25 March 2015 - Accepted 11 September 2015

\begin{abstract}
Introduction. Deciduous tree fruits like peach (Prunus persica (L.) Batsch var. persica), nectarine (Prunus persica (L.) Batsch var. nucipersica (Suckow) C.K.Schneid), and especialy plum (Prunus domestica L. ssp. domestica) are very common in Serbia. These fruits are known for their nutritional value and therapeutic properties and are valuable sources of antioxidants. Materials and methods. The goal of this work was to evaluate fruit tissue antioxidant activity using methanol extracts of 9 peach, 3 nectarine and 7 plum cultivars. The following parameters were measured: total phenolic content (TPC); antioxidant activity as estimated by radical scavenging activity of (2,2-diphenyl-1picrylhydrazyl, DPPH); cation decolorization activity (2,2-azinobis-3 ethylbenxothiazoline-6-sulphonic acid, ABTS); ferric reducing antioxidant power (FRAP); cupric reducing antioxidant capacity (CUPRAC); and total reducing power (TRP). Results and discussion. Total phenolic contents of the plum cultivars were higher than those of peach and nectarine and significant positive correlations were recorded between all antioxidant activity assays and total phenolic contents. Results obtained by principal component analysis (PCA) are in agreement with those obtained by cluster analysis (CA). Conclusion. The selected methods revealed antioxidant activities for all plum cultivars significantly higher than in the peach and nectarine cultivars. PCA and CA allow grouping the different fruit species based on TPC, DPPH, ABTS, TRP, FRAP and CUPRAC values.
\end{abstract}

Keywords: Serbia / peach / plum / nectarine / Prunus spp. / antioxidant activity / phenolics

Résumé - Caractérisation chimiométrique de cultivars de pêches, nectarines et prunes en fonction de la teneur
en composés phénoliques et de l'activité antioxydante de leurs fruits. Introduction. Les fruits à noyau apparentés
aux pêches (Prunus persica (L.) Batsch var. persica), nectarine (Prunus persica (L.) Batsch var. nucipersica (Suckow)
C.K.Schneid), et surtout aux prunes (Prunus domestica L. ssp. domestica) sont très courants en Serbie. Ces fruits sont
connus pour leur valeur nutritionnelle et leurs propriétés thérapeutiques, et ils sont une source précieuse d'antioxydants.
Matériels et méthodes. Le but de ce travail était d'évaluer les activités anti-oxydantes des extraits méthanoliques des
fruits de 9 cultivars de pêcher, 3 cultivars de nectarine et 7 cultivars de prunier. Les paramètres suivants ont été mesurés :
le contenu phénolique total (PTC); l'activité anti-oxydante par piégeage des radicaux (2,2-diphényl-1-picrylhydrazyl
ou DPPH); l'activité de décoloration cationique (acide 2,2-azinobis 3 -éthyl-6-benxothiazoline sulfonique ou ABTS);
l'activité anti-oxydante ferrique (FRAP) ou cuivrique (CUPRAC); et la puissance réductrice totale (TRP). Résultats
et discussion. Le contenu total en composés phénoliques des cultivars testés de prune était plus élevé que celui des
cultivars de pêche et de nectarine. Une corrélation positive significative a été enregistrée entre tous les dosages d'activité
anti-oxydante et la teneur totale en composés phénoliques. Les résultats obtenus par analyse en composante principale
(PCA) sont en accord avec ceux obtenus par analyse de clusters (CA). Conclusion. Les méthodes analytiques choisies
ont révélé de fortes activités anti-oxydantes pour tous les cultivars de prune, qui sont significativement plus élevées
par rapport aux résultats correspondants pour les cultivars de pêche et de nectarine. La PCA et la CA ont permis le
regroupement des différentes espèces fruitières sur la base des valeurs de PTC, DPPH, ABTS, TRP, FRAP et CUPRAC.

Mots clés : Serbie / pêcher / prunier / nectarine / Prunus spp. / activité anti-oxydante / composés phénoliques

\footnotetext{
^ Corresponding author: violetamitic@yahoo.com
} 


\section{Introduction}

Balanced diets, including the regular consumption of fruits play a major protective role against many diseases such as: different types of cancer, cardiovascular diseases, osteoporosis and atherosclerosis cellular aging [1].

Fruits are valuable sources of nutrients, vitamins, minerals, dietary fiber, nonessential phytochemicals, water, and especially an abundance of antioxidant compounds. Antioxidants are compounds that may inhibit, retard or delay the oxidation of other molecules by inhibiting the initiation or propagation of oxidizing chain reactions [2]. Phytochemicals that are known for strong antioxidant activity are polyphenols, carotenoids and vitamins (A, C, E), all known to be beneficial for improving human health [3].

Peach and nectarine (Prunus persica (L.) Batsch vars. persica and nucipersica) (family Rosaceae) represent one of the most important deciduous fruit crops in the world after apple and pear. They are summer fruit, widely cultivated in the temperate regions of the world, especially in the Italy, Spain, France, Greece, United States and China [4-6]. Prunus persica is known for its nutritional value and therapeutic properties. Major constituents of $P$. persica fruit are carbohydrates, organic acids, minerals and dietary fibers [7] which contribute to its nutritional quality [8]. Ripe peach and nectarine fruits have a white or golden yellowish flesh and a sweet taste due to lower acidity. Peaches as well as some other Rosaceae family fruits are rich in vitamin A and potassium as well as in organic acids and sugars [9].

Including peaches in the diet can suppress reactive oxygen species (ROS) in human plasma and provide protection against chronic diseases [10]. Peach fruits have laxative properties and are thus appropriate for preventing constipation and for the treatment of duodenum ulcers [7]. Nectarine and peach are closely related, differing mainly in the fact that nectarine lacks fruit surface pubescence. Nectarines tend to be somewhat smaller than peaches and some have a firmer texture and sweeter flavor. Both nectarines and peaches are low in calories and contain no saturated fats. They are a source of some of B-complex vitamins including niacin, pantothenic acid, thiamin, and pyridoxine. In addition, they contain an appropriate ratio of minerals and electrolytes such as potassium, iron, zinc, copper and phosphorus.

Plum fruits (Prunus domestica L. ssp. domestica) have low calorie content and a low glycemic index score but relatively high nutritive value. They contain carbohydrates, first of all sucrose, glucose and fructose, organic acids, e.g. citric and maleic acids, fibers (pectins), tannins, aromatic substances, chlorophyll, carotenoids, anthocyanins and enzymes. These substances determine nutritive value and taste of plums [12]. Plum is a fruit rich in phenolic compounds, characterized by relatively high antioxidant activity, higher than for example orange, apple or strawberries [13]. The taste of plum depends of the relation of sugars and organic acids. Plums are also rich in many minerals and vitamins $(\mathrm{C}, \mathrm{A}, \mathrm{B} 1, \mathrm{~B} 2)$. Ascorbic acid is the best known antioxidant and an important molecule in plant tissues that protects plants against oxidative damage caused by the oxidative metabolites of photosynthesis and aerobic processes [14].
Plum has high potassium content and an advantageous sodium/potassium ratio [15] that slows down the absorption of carbohydrates, enhances the sensation of satiety, reduces blood serum triglycerides and homocysteine concentrations as well as the levels of total cholesterol and its LDL fraction, and increases lipid breakdown in the human organism. The consumption of plum remains low despite reports that this tasty fruit with intensive aroma is an important source of compounds with benefits for human health. This might be due to the lack of maturity of the marketed fruit [16].

Peach, nectarine and plum tissues contain ample amounts of polyphenols, carotenes and anthocyanins [17], flavonols such as quercetin 3-rutinoside, hydroxycinnamates such as chlorogenic acid and neochlorogenic acid, and flavan 3-ols such as catechin and epicatechin $[18,19]$. The main anthocyanins reported in peach and plum were cyanidin 3-glucoside and cyanidin 3-rutinoside [18,19], cyanidin 3-acetyl glucoside, cyanidin 3-galactoside [19], peonidin-3-glucoside and peonidin derivatives [18]. Similar phenolic profiles were detected for both nectarine and peach, and no differences were found between white-flesh and yellow-flesh peach cultivars [20]. Phenolic compounds $[7,21]$ do not have essential importance to the peach and nectarine plant itself, but can affect the quality of fruit sensorial-organoleptic attributes (flavor, aroma, and color), as well as nutritional quality.

The antioxidant content in examined fruits varies greatly across cultivar type (peach, nectarine or plum) [22], growing practices, geographic location and environmental factors (water and light availability, soil composition, stresses, etc.) $[3,5]$. Furthermore, as happens for other fruits that are often picked unripe for commercial handling purposes, peach antioxidant content may be affected by the stage of fruit ripening at harvest, storage techniques [12] and time elapsed between harvest and consumption [5]. Although phenolic compounds have bioactivities which could have a positive impact on health [23], they could provoke undesirable effects such as astringency and bitterness $[1,7,24,25]$. Carotenoids from peach and nectarine [26] especially $\beta$-carotene, lutein and $\beta$ cryptoxanthin [2] have a role as pigments but also have a protective role against oxidative stress in plant cells [5].

Published data about the contents of phenolic compounds and total antioxidant activity of peach and nectarine methanol extracts are insufficient. Taking into account that these natural antioxidants are multifunctional, the antioxidant capacities of samples cannot be completely described with one single method. Also, since the methods are different from each other in terms of assay principles reaction conditions, and expression of results, one single method is not enough to show all the antioxidant proprieties of examined fruits.

The objective of this study was to compare different peach, nectarine, and plum cultivars to determine fruit phenolic content and antioxidant capacity. This was done by applying five widely used spectrophotometric methods: DPPH, ABTS, FRAP, CUPRAC, TRP and estimating the correlation of antioxidant capacities with total phenolic content. To the authors' knowledge, clustering of different peach and nectarine species based on their antioxidant activity and total phenolic content was done for the very first time. 


\section{Materials and methods}

\subsection{Plant materials}

Peach, nectarine and plum fruits of various cultivars were collected from orchards in Serbia. Five to ten fruits at the firm ripe stage were chosen from each cultivar of peach ('Maycrest', 'Cardinal', 'Cresthaven', 'Redhaven', 'Colins', 'J.H. Hale', 'Maja', 'Golden', 'Vinogradarska'), nectarine ('Caldesi', 'Fantasia', 'Crimson gold') and plum ('Ruska dzanarika', 'Cacanska lepotica', 'Cacanska rodna', 'Cacanski secer', 'Cacanska najbolja', 'Stanley', 'Moravka'). Fruits were collected during harvest season between June and September 2014 in a rural unpolluted area of Soko Banja (peach and nectarine) and Blace (plum) in South Eastern Serbia.

Fruit tissue (without peel) of frozen peach, nectarine and plum $(10 \mathrm{~g})$ was homogenized in a blender. Four consecutive extractions were performed with $15 \mathrm{~mL}$ methanol and $15 \mathrm{~min}$ in an ultrasonic bath. These extracts were filtered, and diluted with methanol to a final volume of $25 \mathrm{~mL}$.

\subsection{Chemicals and instruments}

Chemicals and reagents were purchased from Merck (Darmstadt, Germany). Spectrophotometric assays were performed on a double-beam UV-VIS spectrophotometer Perkin Elmer lambda 15 (MA, USA). Each sample was analyzed in triplicate.

\subsection{Antioxidant activity}

\subsubsection{Total phenolic content (TPC)}

Total phenolic content and the five estimates of antioxidant activity all involved the procedures described by Dimitrijevic et al. [27]. For total phenolic content, $0.05 \mathrm{~mL}$ of the extract was mixed with $0.5 \mathrm{~mL}$ of Folin-Ciocalteu reagent, $2 \mathrm{~mL}$ sodium carbonate solution and $4 \mathrm{~mL}$ water. The reaction was carried out in the dark for $30 \mathrm{~min}$ and absorbance was measured at $750 \mathrm{~nm}$. Gallic acid was used to calculate the standard curve and the results were expressed as $\mathrm{mg}$ of gallic acid equivalents (GAE) per $g$ of fresh weight $\left(\mathrm{mg} \mathrm{GAE} \mathrm{g}^{-1} \mathrm{fw}\right)$.

\subsubsection{DPPH radical scavenging capacity}

For the quantitative assays of the methanol extracts for DPPH radical scavenging capacity, $1.5 \mathrm{~mL}$ of DPPH radical methanol solution at the concentration of $100 \mathrm{mmol} \mathrm{L}^{-1}$, $0.1 \mathrm{~mL}$ extract at the concentration of $20 \mathrm{mg} \mathrm{mL}^{-1}$ fruit tissue. and methanol to a total volume of $4 \mathrm{~mL}$, were placed in a test tube. The mixture was shaken and after $60 \mathrm{~min}$ in the dark, the absorbance was measured at $515 \mathrm{~nm}$. The percentage of scavenging activity was calculated as:

$$
A \%=((A c-A s) / A c) \times 100
$$

where Ac is the absorbance of control (without sample), and As is the absorbance of sample.

\subsubsection{ABTS radical scavenging activity}

The ABTS radical was produced by the reaction of ABTS stock solution with potassium persulfate and the mixture was allowed to stand in the dark at $25{ }^{\circ} \mathrm{C}$ for $12-16 \mathrm{~h}$ before use. The solution was then diluted by mixing $7 \mathrm{~mL} \mathrm{ABTS}^{+}$solution with $120 \mathrm{~mL}$ methanol to obtain an absorbance of $0.70 \pm$ 0.02 units at $734 \mathrm{~nm}$. An aliquot of each extract, at the concentration of $20 \mathrm{mg} \mathrm{mL}^{-1}$, was mixed with $1.8 \mathrm{~mL}$ of diluted $\mathrm{ABTS}^{++}$solution at the concentration of $7 \mathrm{mmol} \mathrm{L}^{-1}$ and diluted with methanol to a total volume of $4 \mathrm{~mL}$. After $6 \mathrm{~min}$ at $25^{\circ} \mathrm{C}$, the reduction in absorbance was measured at $734 \mathrm{~nm}$. The percentage of scavenging activity was calculated applying Equation 1.

\subsubsection{Ferric-reducing antioxidant power (FRAP) assay}

One $\mathrm{mL}$ of FRAP reagent was mixed with $0.05 \mathrm{~mL}$ of sample, at the concentration of $20 \mathrm{mg} \mathrm{mL}^{-1}$, and diluted with water to make up a volume of $4 \mathrm{~mL}$. After $5 \mathrm{~min}$ incubation at $37^{\circ} \mathrm{C}$, the absorbance was recorded at $595 \mathrm{~nm}$. FRAP values expressed as mmol of $\mathrm{Fe}^{2+}$ equivalents per $\mathrm{g}$ fresh weight ( $\mathrm{mmol} \mathrm{Fe} \mathrm{g}^{-1} \mathrm{fw}$ ) were obtained by comparing the absorption change in the test mixture with doses obtained from the $\mathrm{Fe}(\mathrm{II})$ standard calibration curve.

\subsubsection{Total reducing power (TRP) assay}

Reaction mixtures were prepared by mixing $0.01 \mathrm{~mL}$ of extract, $1 \mathrm{~mL}$ of $1 \%$ solution $\mathrm{K}_{3}\left[\mathrm{Fe}(\mathrm{CN})_{6}\right]$, phosphate buffer (pH 6.6) and water. The mixtures were incubated at $50{ }^{\circ} \mathrm{C}$ for $30 \mathrm{~min}$ and then $1 \mathrm{~mL} 10 \%$ solution of trichloroacetic acid and $0.6 \mathrm{~mL} \mathrm{FeCl}_{3}$ were added. Results were expressed as mg ascorbic acid equivalents per $g$ of fresh weight ( $\mathrm{mg} \mathrm{AAE} \mathrm{g}^{-1} \mathrm{fw}$ ).

\subsubsection{Cupric reducing antioxidant capacity (CUPRAC) assay}

This assay involved the addition of $0.05 \mathrm{~mL}$ of extract, $1 \mathrm{~mL}$ of phosphate buffer ( $\mathrm{pH} 7.0)$, neocuproine concentration of $7.510^{-3} \mathrm{~mol} \mathrm{~L}^{-1}$, copper (II) - chloride at the concentration of $0.01 \mathrm{~mol} \mathrm{~L}^{-1}$, and diluted with water to a total volume of $4.1 \mathrm{~mL}$. The mixture was left for $30 \mathrm{~min}$ at $25{ }^{\circ} \mathrm{C}$ and after that, absorbance was measured at $450 \mathrm{~nm}$. Trolox was used as a standard and results were expressed as mg Trolox equivalents per $g$ of fresh weight ( $\left.\mathrm{mg} \mathrm{TE}^{-1} \mathrm{fw}\right)$.

\subsection{Statistical Analysis}

Data analysis involved several procedures. The elimination of outliers was carried out by Grubb's test. All data were reported as the mean \pm standard deviation of three replicates $(n=3)$. Correlation analysis examined the interrelationships between the study samples. Cluster analyses (CA) was carried out with the total phenolic content and antioxidant activity data 
Table I. Total phenolic contents (TPC) and antioxidant activity criteria of several Prunus fruit cultivars grown in Serbia (DPPH: 2,2diphenyl-1-picrylhydrazyl radical scavenging activity; ABTS: 2,2'-azino-bis(3-ethylbenzothiazoline-6-sulphonic acid) radical scavenging activity; CUPRAC: cupric reducing antioxidant capacity; TRP: total reducing power; FRAP: ferric reducing antioxidant power). Values are means $\pm \operatorname{SD}(n=3)$.

\begin{tabular}{|c|c|c|c|c|c|c|c|}
\hline $\begin{array}{l}\text { Prunus } \\
\text { species }\end{array}$ & Cultivars & $\mathrm{DPPH}(\%)^{\mathrm{y}}$ & $\operatorname{ABTS}(\%)^{\mathrm{y}}$ & $\begin{array}{c}\text { TPC } \\
\left(\mathrm{mg} \mathrm{GAE} \mathrm{g}^{-1}\right)\end{array}$ & $\begin{array}{l}\text { CUPRAC }^{\mathrm{y}} \\
\left(\mathrm{mg} \mathrm{TE} \mathrm{g}^{-1}\right)\end{array}$ & $\begin{array}{c}\text { TRP }^{\mathrm{y}} \\
\left(\mathrm{mg} \mathrm{AAE}^{-1}\right)\end{array}$ & 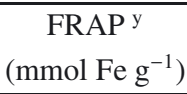 \\
\hline \multirow{9}{*}{ Peach } & Maycrest & $13.49 \pm 1.09^{\mathrm{cd}}$ & $16.67 \pm 2.94^{\text {cde }}$ & $1.28 \pm 0.02^{\mathrm{g}}$ & $0.28 \pm 0.02^{\mathrm{p}}$ & $15.52 \pm 3.23^{\mathrm{gh}}$ & $0.48 \pm 0.02^{\mathrm{i}}$ \\
\hline & Cardinal & $17.30 \pm 1.77^{\mathrm{bcd}}$ & $24.16 \pm 3.02^{\mathrm{cd}}$ & $2.03 \pm 0.03^{\mathrm{g}}$ & $0.32 \pm 0.02^{q}$ & $18.41 \pm 2.54^{\mathrm{fgh}}$ & $0.80 \pm 0.03^{\mathrm{g}}$ \\
\hline & Cresthaven & $16.98 \pm 1.51^{\mathrm{cd}}$ & $31.50 \pm 3.75^{\mathrm{c}}$ & $1.78 \pm 0.02^{\mathrm{g}}$ & $0.32 \pm 0.02^{q}$ & $19.69 \pm 3.01^{\mathrm{fg}}$ & $0.67 \pm 0.02^{h}$ \\
\hline & Redhaven & $14.13 \pm 1.16^{\mathrm{cd}}$ & $12.69 \pm 2.96^{\mathrm{e}}$ & $0.69 \pm 0.01^{\mathrm{gh}}$ & $0.24 \pm 0.01^{\mathrm{r}}$ & $13.30 \pm 3.51^{\mathrm{gh}}$ & $0.31 \pm 0.02^{\mathrm{i}}$ \\
\hline & Collins & $17.94 \pm 2.16^{\mathrm{abcd}}$ & $30.58 \pm 3.13^{c}$ & $1.78 \pm 0.08^{\mathrm{g}}$ & $0.32 \pm 0.02^{q}$ & $15.24 \pm 3.51^{\mathrm{gh}}$ & $0.67 \pm 0.03^{h}$ \\
\hline & J. H. Hale & $16.67 \pm 1.75^{\mathrm{cd}}$ & $44.80 \pm 4.71^{\mathrm{c}}$ & $4.00 \pm 0.04^{\mathrm{e}}$ & $0.45 \pm 0.02^{\mathrm{g}}$ & $24.55 \pm 2.68^{\mathrm{ef}}$ & $1.06 \pm 0.04^{\mathrm{f}}$ \\
\hline & Maja & $15.24 \pm 1.68^{\mathrm{cd}}$ & $13.76 \pm 1.85^{\mathrm{de}}$ & $0.55 \pm 0.01^{\mathrm{h}}$ & $0.24 \pm 0.02^{\mathrm{r}}$ & $12.31 \pm 1.45^{\mathrm{h}}$ & $0.28 \pm 0.02^{\mathrm{i}}$ \\
\hline & Golden & $17.46 \pm 1.84^{\mathrm{abcd}}$ & $26.30 \pm 3.75^{\mathrm{c}}$ & $1.69 \pm 0.02^{\mathrm{g}}$ & $0.31 \pm 0.02^{\mathrm{q}}$ & $17.22 \pm 1.68^{\mathrm{fgh}}$ & $0.69 \pm 0.02^{\mathrm{h}}$ \\
\hline & Vinogradarska & $17.94 \pm 2.08^{\mathrm{abcd}}$ & $44.19 \pm 4.09^{c}$ & $3.17 \pm 0.02^{\mathrm{fg}}$ & $0.40 \pm 0.02^{\mathrm{h}}$ & $23.62 \pm 1.92^{f}$ & $1.15 \pm 0.03^{f}$ \\
\hline \multirow{3}{*}{ Nectarine } & & $18.10 \pm 1.98^{\mathrm{abcd}}$ & $22.78 \pm 3.39^{\text {cde }}$ & $1.83 \pm 0.15^{\mathrm{g}}$ & $0.33 \pm 0.01^{q}$ & $17.58 \pm 1.87^{\text {fgh }}$ & $0.73 \pm 0.03^{\mathrm{h}}$ \\
\hline & Fantasia & $13.02 \pm 1.01^{\mathrm{cd}}$ & $11.93 \pm 2.06^{\mathrm{e}}$ & $1.08 \pm 018^{\mathrm{gh}}$ & $0.25 \pm 0.01^{\mathrm{kr}}$ & $15.07 \pm 1.82^{\mathrm{gh}}$ & $0.39 \pm 0.02^{\mathrm{i}}$ \\
\hline & Crimson gold & $15.40 \pm 2.28^{\mathrm{cd}}$ & $12.84 \pm 2.74^{\mathrm{de}}$ & $0.93 \pm 0.51^{\mathrm{gh}}$ & $0.26 \pm 0.01^{\mathrm{pk}}$ & $14.36 \pm 1.38^{\mathrm{gh}}$ & $0.49 \pm 0.02^{\mathrm{i}}$ \\
\hline \multirow{7}{*}{ Plum } & Ruska dzanarika & $32.86 \pm 3.75^{\mathrm{ab}}$ & $72.32 \pm 4.63^{\mathrm{abc}}$ & $6.42 \pm 1.29^{c}$ & $0.63 \pm 0.03^{\mathrm{d}}$ & $34.25 \pm 2.51^{\mathrm{d}}$ & $2.74 \pm 0.02^{\mathrm{d}}$ \\
\hline & Cacanska lepotica & $32.86 \pm 3.28^{\mathrm{ab}}$ & $82.26 \pm 4.47^{\mathrm{ab}}$ & $5.94 \pm 1.07^{\mathrm{d}}$ & $0.61 \pm 0.01^{\mathrm{e}}$ & $32.43 \pm 2.84^{\mathrm{de}}$ & $2.40 \pm 0.02^{\mathrm{e}}$ \\
\hline & Cacanska rodna & $40.03 \pm 3.51^{\mathrm{ab}}$ & $83.94 \pm 5.33^{\mathrm{ab}}$ & $4.43 \pm 0.93^{\mathrm{e}}$ & $0.52 \pm 0.03^{\mathrm{f}}$ & $29.01 \pm 2.93^{\mathrm{de}}$ & $1.50 \pm 0.01^{\mathrm{f}}$ \\
\hline & Stanley & $38.25 \pm 2.75^{\mathrm{ab}}$ & $78.59 \pm 4.97^{\mathrm{ab}}$ & $8.33 \pm 1.48^{c}$ & $0.83 \pm 0.05^{\mathrm{c}}$ & $40.64 \pm 3.04^{c}$ & $3.56 \pm 0.03^{\mathrm{c}}$ \\
\hline & Moravka & $40.79 \pm 3.26^{\mathrm{a}}$ & $86.39 \pm 5.09^{\mathrm{a}}$ & $3.91 \pm 0.92^{\mathrm{ef}}$ & $0.44 \pm 0.02^{g}$ & $28.65 \pm 3.61^{\mathrm{e}}$ & $1.47 \pm 0.02^{\mathrm{f}}$ \\
\hline & Cacanska najbolja & $32.70 \pm 1.88^{\mathrm{abc}}$ & $66.82 \pm 4.34^{\mathrm{bc}}$ & $9.41 \pm 1.28^{\mathrm{b}}$ & $0.88 \pm 0.04^{b}$ & $53.39 \pm 6.92^{\mathrm{b}}$ & $3.89 \pm 0.04^{\mathrm{b}}$ \\
\hline & Cacanska secer & $33.49 \pm 2.98^{\mathrm{ab}}$ & $53.06 \pm 4.11^{\mathrm{c}}$ & $13.53 \pm 1.85^{\mathrm{a}}$ & $1.11 \pm 0.06^{\mathrm{a}}$ & $58.30 \pm 7.68^{\mathrm{a}}$ & $6.02 \pm 0.09^{\mathrm{a}}$ \\
\hline
\end{tabular}

y Values with different letters within columns are statistically different at $P<0.05$ by a statistical test on the means (LSD).

to identify various groups. The CA produced a dendrogram by means of the Ward's method of hierarchical clustering, based on the Euclidean distance between pairs of fruit samples.

Principal component analysis (PCA) was performed as it is among the best-known multivariate analysis methods for determining relationships among variables [28]. All computations were done using the Statistica 8 software (StatSoft, Tulsa).

\section{Results and discussion}

\subsection{Fruit phenolic contents}

Polyphenols play an important role in antioxidant activity. The results of total phenol content, determined by FolinCiocalteu's method, are reported in table I. The polyphenol content of fruit is influenced by numerous factors such as genotype, rootstock, climatic conditions, agronomic practices, harvesting time, and postharvest conditions. Also, the results of total phenolic content depend on sample preparation technique, the assay standards (gallic acid, tannic acid), and the methods used to identify and quantify potential antioxidants (spectrophotometric determination or HPLC-DAD).

The total content of phenolic substances ranged from 0.55 to $4.01 \mathrm{mg}$ GAE $\mathrm{g}^{-1} \mathrm{fw}$ for peach and 0.93 to $1.83 \mathrm{mg} \mathrm{GAE} \mathrm{g}^{-1} \mathrm{fw}$ for nectarine. The lowest total phenol content was determined in the early peach cv. 'Maja' and highest in the late cv. 'J.H. Hale'. Similarly, the late-season cv. 'Vinogradarska' had significantly higher phenolic content (3.17 mg GAE $\mathrm{g}^{-1} \mathrm{fw}$ ) compared to other cultivars and it appears that late season peaches tend to exhibit higher total phenolic content.

However, nectarine followed a different trend: the highest total phenolic content was determined in the early cv. 'Caldesi' $\left(1.83 \mathrm{mg} \mathrm{GAE} \mathrm{g}^{-1} \mathrm{fw}\right)$ and the lowest in late cultivar 'Fantasia' $1.08 \mathrm{mg} \mathrm{GAE} \mathrm{g}^{-1} \mathrm{fw}$.

Total phenolic contents in plum ranged from $3.91 \mathrm{mg} \mathrm{GAE} \mathrm{g}^{-1} \mathrm{fw}$ in 'Moravka' to 13.53 in 'Cacanski secer'. Other high phenol cultivars were 'Stanley' (8.33) and 'Cacanska najbolja' (9.41). These values are almost five times higher than published results [29] for 'Stanley' (1.74) and almost three times more for 'Cacanska najbolja' (3.19).

Considering that all plum cultivars were grown under identical conditions and in the same locality, it is possible to conclude that our results are strongly influenced by varietal variability, which is quite typical of plum. We observed higher contents of phenolics and stronger antioxidant activities in regional plum cvs ('Cacanska najbolja', 'Cacanski secer') than in more commercial ones (e.g. 'Stanley').

In general, the phenolic contents found in plum were significantly higher than those reported for peach and nectarine. It is very difficult to compare our data on total phenolic content with published data. Moreover, phenolic compounds are not 
uniformly distributed within the fruit tissue, and most of them are concentrated in the epidermal and sub epidermal layers of the fruit, so it is very important how fruits material was prepared - with or without peel tissues. Phenolic distribution is an important aspect of the overall phenolic composition and antioxidant capacity because peach skin is usually not eaten and therefore it does not contribute to the human diet. In general, the values we obtained are comparable to data reported in the literature expressed as $\mathrm{mg} \mathrm{GAE} \mathrm{g}^{-1}$ fw: 0.74 [30]; 0.70 [31]; 0.33 [32]; 0.28 [33]; 0.29-0.55 [5]. In fruit samples from Croatia [34], phenolic content of the peach cv. 'Redhaven' was 0.41 mg GAE $\mathrm{g}^{-1} \mathrm{fw}$, very similar to what we determined (0.69) for the same cultivar. Since higher values of phenolic content were determined in peach samples from Italy and Korea (3.95-7.28 $\mathrm{mg} \mathrm{GAE} \mathrm{g}^{-1}$ fw [3], $4.03 \mathrm{mg} \mathrm{GAE} \mathrm{g}^{-1}$ fw [35], respectively), climatic conditions might be responsible for the differences observed.

Our results for total phenolic content of different plum cultivars were comparable with the recent reports from other origins (in mg GAE $\mathrm{g}^{-1} \mathrm{fw}$ ): 3.48-4.95 [36]; 1.25-3.72 [18]; 1.60-3.00 [37]; 2.37 [38]; 1.29-6.25 [39]; $2.82-9.22[40,41])$.

\subsection{Fruit antioxidant activities}

To determine free radical scavenging activity of peach, nectarine and plum extracts, we used two types of radicals, DPPH and ABTS. Antioxidants interacting with these radicals transfer an electron, thus neutralizing an unpaired electron. Electron transfer-based DPPH and ABTS assays generally set a fixed time for the redox reaction and measure thermodynamic conversion (oxidation) during that period.

DPPH radical activity can be expressed in many different ways, making the comparison of obtained data with previously reported data very difficult [42]. The majority of authors evaluated DPPH activity via evaluation of $\mathrm{EC}_{50}$ (the sample concentration necessary to reduce the initial DPPH activity to $50 \%$ ), or percentage inhibition (\%). DPPH has been widely used for free radical-scavenging assessments due to its simplicity and convenience. In the present study, peaches' and nectarines' extracts were found to be very similar in their ability as DPPH radical scavengers (table I). The results of examined peach extracts were in the range $13.50-17.94 \%$ inhibition of DPPH radical. The highest values came from the peach cultivars 'Vinogradarska' and 'Colins' (17.94\%). The cv. 'Redhaven' inhibited $14.13 \%$ of DPPH radical. The highest DPPH free radical scavenging capacity amongst nectarine cultivars came from the early cv. 'Caldesi' (18.01\%); the lowest came from the late cv. 'Fantasia' (13.02\%).

These results differ slightly from those reported earlier [34], which is probably the consequence of different cultivars being studied. However, they are very similar to some other results [42] for similar cultivars.

Antioxidant capacity of plum extracts, as evaluated by the DPPH radical scavenging assay, was in the range of double that found for peach and nectarine, ranging from $32.70 \%$ (' $\mathrm{Ca}$ canska najbolja') to $40.79 \%$ ('Moravka') (table I). The high scavenging property of plum extracts may be due to hydroxyl groups existing in the phenolic compounds' chemical structure that can provide the necessary component as a radical scavenger.

ABTS method is also a common method for determination of antioxidant activity of extracts and is based on the decolorization of the $\mathrm{ABTS}^{+}$cation radical. Various peach cultivars showed statistically significant differences in antioxidant activity estimated by this method (table I). The cultivar 'Vinogradarska' possessed a strong scavenging capacity for the $\mathrm{ABTS}^{+}$radical $(44.20 \%)$ and was very similar to that for 'J.H. Hale' (44.80\%). These late peach cultivars showed stronger activity against ABTS radical than early varieties (12.69\% and $13.76 \%$, 'Redhaven' and 'Maja'). These results could be explained by the fact that 'J.H. Hale' and 'Vinogradarska' have significantly higher phenolic content (4.01 and $3.17 \mathrm{mg} \mathrm{GAE} \mathrm{g}^{-1} \mathrm{fw}$ ) compared to other cultivars.

The nectarine cv. 'Fantasia' exhibited ABTS-estimated antioxidant acitivity (11.93\%) only half that of the $\mathrm{cv}$. 'Caldesi' (22.78\%). Amongst the peach and nectarine cultivars, 'Vinogradarska' showed the highest antioxidant capacity considering both methods.

As was the case for the DPPH assay, ABTS-estimated antioxidant activity for the plums was significantly higher for peach and nectarine (table I). The antioxidant activity in plum is known to be dependent on the cultivar [18, 34, 43]. We found that 'Moravka' had the highest ABTS-estimated activity $(88.39 \%)$ followed by 'Cacanska rodna' (83.94\%) and 'Cacanska lepotica' (82.63\%). The lowest activity was shown for ' $\mathrm{Ca}$ canski secer' $(55.06 \%)$, but it is still double that of the highest result for nectarine.

In this study FRAP, CUPRAC and TRP assays were also used to estimate the reductive capacity of the examined extracts (table I). Previously reported data for the FRAP [30, $33,45,46]$, CUPRAC and TRP [7] assays of peach and plum extracts were considered insufficient and partly contradictory. This is due not only to different contents and proportions of particular phenolic compounds in different cultivars of peach, nectarine and plum, but above all to different methods and the various methodological approaches that were used. The comparison of literature data is thus very complicated and even impossible in some cases because of the different standard substances used.

Nectarine tended to have lower values obtained by FRAP assay $\left(0.39-0.73 \mathrm{mmol} \mathrm{Fe} \mathrm{g}^{-1} \mathrm{fw}\right)$ compared to peach $(0.28-1.15)$ but a wide variation in the total antioxidant capacity and phenolic content of peach was observed among cultivars. The peach cultivar showing the highest antioxidant capacity by this measure was 'Vinogradarska' (1.15) followed by 'J.H. Hale' (1.06). In contrast, 'Maja' (with the lowest phenolic content) showed low $\mathrm{Fe}^{2+}$ reduction activity $\left(0.28 \mathrm{mmol} \mathrm{Fe} \mathrm{g}^{-1} \mathrm{fw}\right)$. Amongst the nectarine cultivars, 'Fantasia' showed low antioxidant activity (0.39), while 'Caldesi' (0.73) had both the highest antioxidant capacity and highest phenolic content.

The highest antioxidant activity was found among the plum cultivars. However, these levels overlapped those found among the other examined fruits. Among the seven plum cultivars, 'Cacanski secer' showed the highest antioxidant activity $\left(6.02 \mathrm{mmol} \mathrm{Fe} \mathrm{g}^{-1} \mathrm{fw}\right)$, whereas 'Moravka' had the lowest 
(1.47). Values of antioxidant activity obtained by FRAP assay for 'Cacanska najbolja' and 'Stanley' were very similar (3.89 and 3.56, respectively).

The CUPRAC method for determining antioxidant activity had not been done until now on peach and nectarine. Nectarine cultivars ('Fantasia', 'Caldesi') expressed lower values (0.25-0.33 mg TE g $\left.{ }^{-1} \mathrm{fw}\right)$ compared to values observed for peach (0.24 in 'Maja' and 'Redhaven', 0.45 for 'J.H. Hale'). Early varieties of nectarine had lower CUPRAC values than late ones, which is different from peach. The highest CUPRAC values in peach were found in 'J.H. Hale' $(0.45)$ and in the late cv. 'Vinogradarska' (0.40). All plum cultivars had higher CUPRAC values than the peach and nectarine cultivars examined. Amongst the plum cultivars, 'Cacanski secer' had the highest value, followed by 'Cacanska najbolja' and 'Stanley' (1.11, 0.88 and $0.83 \mathrm{mg} \mathrm{TE} \mathrm{g}^{-1} \mathrm{fw}$, respectively). The lowest antioxidant activity value obtained by this method was found in 'Moravka' (0.44).

Reducing power of the tissue extracts as estimated by the conversion of the $\mathrm{Fe}^{3+} /$ ferricyanide complex to the ferrous form should serve as a significant indicator of its potential antioxidant activity. The best of our knowledge, there are no data about total reducing power of peach and nectarine extracts measured by this method. Total reducing power of nectarine ranged from 14.36-17.58 $\mathrm{mg} \mathrm{AAE} \mathrm{g}^{-1} \mathrm{fw}$ ('Crimson gold', 'Caldesi') and for peach (12.32-24.55 for 'Maja' and 'J.H. Hale'). Plum cv. 'Cacanski secer' showed the greatest reducing power amongst all examined fruits (58.30). Also, the plum cultivar 'Cacanska najbolja' exhibited a high value (53.39). The lowest reducing power values were found in cvs 'Moravka' and 'Cacanska rodna' (29.01 and $28.65 \mathrm{mg} \mathrm{AAE}$ $\mathrm{g}^{-1} \mathrm{fw}$, respectively), which is still greater than the highest values found in peach and nectarine fruits. The antioxidant activity of plum is known to be relatively high compared to other fruit species [46].

The antioxidant (reducing) ability of a sample is associated with the presence of a reductant species that breaks the free radical chain by donating a hydrogen atom or preventing peroxide formation by electron scavenging (ES). Methods used for estimating antioxidant activity are extremely diverse with regard to mechanism and applied reagents and standards. ES-based methods include ABTS and DPPH while TRP, TPC, FRAP and CUPRAC belong to the methods using various chromogenic reagents with different standard redox potentials. The final result of these antioxidant methods (disregarding the mechanism) is mostly similar regarding their capability for quenching or reducing active species. However, their kinetics, eventuality of side reactions, and dependence on reaction conditions may differ. Phenolic and some non-phenolic substances exert different antioxidant activities and the high phenolic contents in fruits may not always lead to higher antioxidant action. Thus, it is of essential importance to estimate antioxidant action using at least one ES and one redox based assay.

Because the antioxidant activity measured by an individual assay reflects only the chemical reactivity under the specific conditions applied in that assay, as pointed out by many authors [48-52], it is inappropriate and misleading to generalize the data obtained by a single method as indicators of antioxidant activity. There are no standardized assays for determining
Table II. Correlations between phenolic content and several antioxidant activity criteria of the tested Prunus species.

\begin{tabular}{lcccccc}
\hline & \multicolumn{7}{c}{ Correlations } \\
\cline { 2 - 7 } & DPPH & ABTS & TPC & CUPRAC & TRP & FRAP \\
\hline DPPH & 1.00 & & & & & \\
ABTS & 0.95 & 1.00 & & & & \\
TPC & 0.73 & 0.67 & 1.00 & & & \\
CUPRAC & 0.74 & 0.68 & 1.00 & 1.00 & & \\
TRP & 0.76 & 0.70 & 0.99 & 0.99 & 1.00 & \\
FRAP & 0.71 & 0.62 & 0.99 & 0.99 & 0.97 & 1.00 \\
\hline
\end{tabular}

antioxidant capacity of any sample, and their "importance" or usefulness depends exclusively on the mechanism of action of antioxidants expected to be found in the particular sample. This is why several antioxidant assays are usually employed in each study, so that the overall antioxidant capacity is evaluated more accurately and all antioxidants compounds are taken into account.

\subsection{Correlations between all measured criteria}

The relationship between antioxidant activity and total phenolic content was tested using correlation analysis. Correlation coefficients are presented in table II. Significant positive correlation values were recorded between all antioxidant activity assays and total phenolic content. The most significant positive correlations were found between TPC/CUPRAC $(r=1, P<0.05)$ and TPC/TRP and TPC/FRAP $(r=0.99$, $P<0.05)$. This indicates that phenolic compounds were the most active compounds measured by the CUPRAC, FRAP and TRP assays. These results are in agreement with Badarinath et al. [53], who reported that CUPRAC findings correlated well with the results of ABTS/TEAC and TPC assays, as well as Yildiz [54], who showed a positive strong correlation between TPC and FRAP antioxidant capacity.

Among antioxidant activity assays, the strongest correlations were found between CUPRAC/FRAP $(r=0.99, P<$ $0.05)$, CUPRAC/TRP $(r=0.99, P<0.05)$, and ABTS/ DPPH $(r=0.95, P<0.05)$, all in agreement with Mitic et al. [55].

Clustering of different peach and plum cultivars based on their antioxidant activity and total phenolic content is presented in figure 1. Cluster analysis grouped the analyzed fruits in two clusters. These clusters were separated due to differences in antioxidant activity and total phenolic content amongst cultivars. Cluster 1 includes peach and nectarine accessions, while plum accessions belong to cluster 2 . The tendency to form natural sample groupings arising from common analytical characteristics is clearly highlighted with such a data analysis procedure. Cluster 1 can be divided into three sub-clusters. Sub-cluster 1 contains five peach cultivars, subcluster 2 contains five, and sub-cluster 3 only two cultivars. Peach in sub-cluster 3 (cvs 'J.H. Hale' and 'Vinogradarska') are late-maturing varieties, characterized by higher ABTS radical scavenging activity. Cluster 2 containing the plum cultivars is characterized by higher antioxidant activity and exhibits two sub-clusters. The smallest Euclidean distance in this cluster was recorded for cvs 'Cacanska rodna'/'Moravka' and 


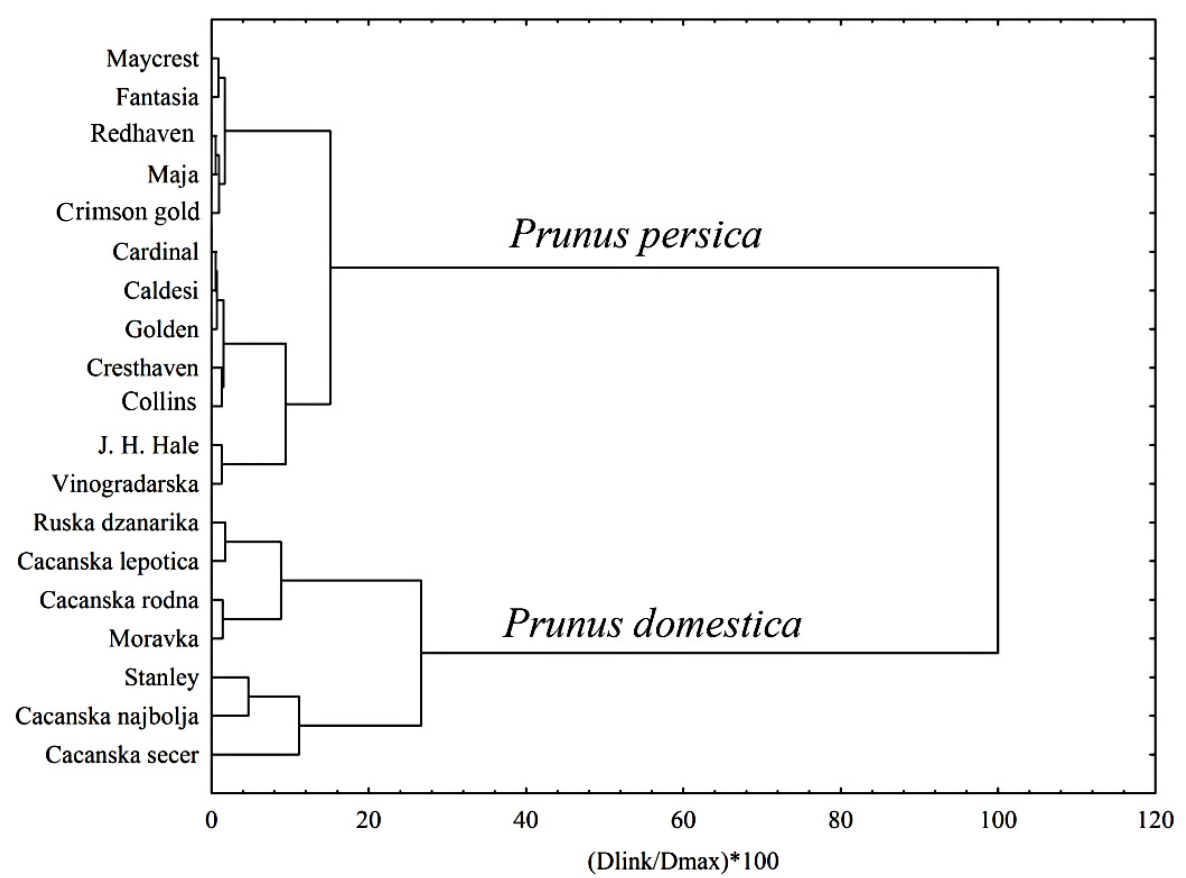

Figure 1. Two-dimensional dendrogram obtained in the cluster analysis of antioxidant activity and total phenol content of peach, nectarine and plum cultivars.

'Ruska dzanarika'/'Cacanska lepotica', indicating their similarity.

Principal component analysis (PCA) was applied to evaluate the data for total phenolic content and antioxidant activity. PCA produced two visual plots: scores and loading (figure 2). The scores plot is a visualization of the differences among accessions, where each fruit sample is plotted on a graph in which the first two or three principal components make up the axes. The loading plot explains the contribution of each variable to the total variance, and shows key variables causing variation in the dataset. $\mathrm{PC} 1$ explained $86.44 \%$ of the total variance and PC2 explained $12.21 \%$, totalizing $98.65 \%$ (figure 2). Variables grouped together were strongly positively correlated (TPC, TRP, CUPRAC and FRAP). Considering the position of the fruit samples it was possible to separate them into two major groups. The first group is made of seven plum varieties, same as in cluster 2 , while peach varieties belong to the second group. Plum accessions are located on the left side of the plot, since they have higher antioxidant activity and total phenolic content compared to peach and nectarine. The plum cv. 'Cacanski secer' is located quite a distance from other accessions, indicating that its antioxidant activity and total phenolic content differs significantly from the other plum samples. Using the plots in figures $2 a$ and $2 b$, it is possible to suggest reasons for the location of accessions on the basis of their antioxidant activity. Location of 'Cacanska najbolja' and 'Cacanski secer' in the lower left-hand quadrant of figure $2 b$ may be explained by their high total phenolic contents and TRP, FRAP and CUPRAC values, which are located in the same quadrant in loading plot. In contrast, peach cultivars had lower values for antioxidant activity analyzed by these as- says, and they are located at the opposite side of the score plot. Plums in the upper left quadrant have higher ABTS and DPPH radical scavenging activity than the other fruit species, which is confirmed by the position of ABTS and DPPH in the loading plot. Results obtained by PCA analysis are in agreement with those obtained from CA.

\section{Conclusion}

The various fruits examined in this study are commonly represented in the traditional human diet in Serbia, and the evaluation of their antioxidant properties is valuable for those interested in consumption patterns (consumers' association, nutrition and health policy makers) as well as for scientists pursuing more comprehensive studies that will encompass more fruit species and broader geographic areas. Having in mind that most consumers recognize fruit mostly at the species level, the results of the present study are valuable for making proper choices of fruit with regard to their antioxidant potential.

Regarding the antioxidant properties of the selected fruit species and varieties, all applied analytical methods (DPPH, ABTS, TRP, FRAP and CUPRAC) are reliable, simple, robust, and they do not require a lot of time for perform, nor complicated and expensive equipment. Although we have found a good correlation among all the methods used here for assessing antioxidant capacity, using more than one antioxidant assay is strongly recommended - a single method will provide basic information about antioxidant properties, but a combination of methods describes the antioxidant properties of the sample in more detail. This is how we can confirm that plum is generally 

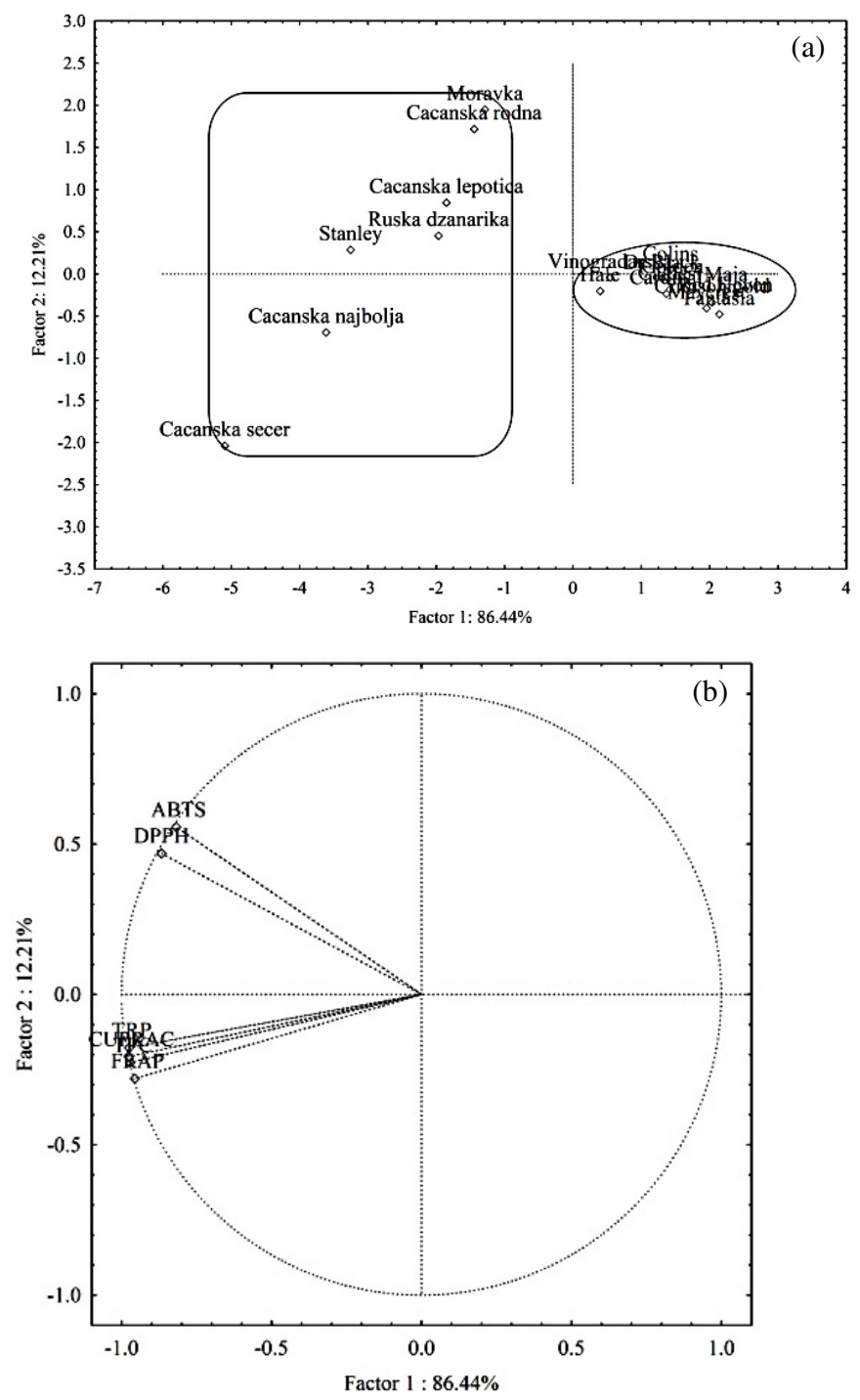

Figure 2. Plot obtained by principal component analysis (PCA); antioxidant activity (measured from DPPH, ABTS, TRP, FRAP and CUPRAC assays) and total phenol content (TPC) are used as variables of peach, nectarine and plum cultivars.

the most potent source of antioxidants, and among the cultivars tested, especially 'Cacanski secer'. Considering all applied assays, the tested peach fruits expressed less than half the antioxidant properties of the tested plums. Among them 'J.H. Hale' and 'Vinogradarska' showed the best characteristics. Nectarine is the fruit species with the lowest antioxidant potential, and among the tested cultivars the best was cv. 'Caldesi', although without significant difference from the other ones.

Fruit maturation has been recognized as an important stage for estimating antioxidant property (FRAP). In the case of peach, late cultivars had significantly higher values than the early ones, while in case of nectarine the relation was reverse. PCA and CA allowed grouping of different fruit species and varieties based on TPC, DPPH, ABTS, TRP, FRAP and CUPRAC values. Also, it should be emphasized that, to our knowledge, these are the first data on the antioxidant activity of these fruit species, determined applying the CUPRAC method.

Acknowledgements. This research work was supported by the Ministry of Education, Science and Technological Development of the Republic of Serbia, through grant no. 172047 for the frame of basic research. This support is deeply appreciated by the authors.

\section{References}

[1] Lock K., Pomerleau J., Causer L., Altmann, D.R. and McKee M., The global burden of disease attributable to low consumption of fruit and vegetables: implications for the global strategy on diet, B. World Health Organ. 83 (2005) 100-108.

[2] Alasalvar C., Shahidi F., Tree Nuts: Composition, phytochemicals, and health effects, CRC Press, Taylor \& Francis Group, Boca Raton, FL, USA, 2008.

[3] Di Vaio C., Graziani G., Marra L., Cascone A., Ritieni A., Antioxidant capacities, carotenoids and polyphenols evaluation of fresh and refrigerated peach and nectarine cultivars from Italy, Eur. Food Res. Technol. 227 (2008) 1225-1231.

[4] Konopacka D., Jesionkowska K., Kruczynska D., Stehr R., Schoorl F., Buehler A., Egger S., Codarin S., Hilaire C., Holler I., Guerra W., Liverani A., Donati F., Sansavini S., Martinelli A., Petiot C., Carbo J., Echeverria G., Iglesias I., Bonany J., Apple and peach consumption habits across European countries, Appetite 55 (2010) 478-483.

[5] Dalla Valle A.Z., Mignani I., Spinardi A., Galvano F., Ciappellano S., The antioxidant profile of three different peaches cultivars (Prunus persica) and their short-term effect on antioxidant status in human, Eur. Food Res. Technol. 225 (2007) 167-172.

[6] Font i Forcada C., Gogorcena Y., Angeles Moreno M., Agronomical parameters, sugar profile and antioxidant compounds of "catherine" peach cultivar influenced by different plum rootstocks, Int. J. Mol. Sci. 15 (2014) 2237-2254.

[7] Manzoor M., Anwar F., Mahmood Z., Rashid U., Ashraf M., Variation in minerals, phenolics and antioxidant activity of peel and pulp of different varieties of peach (Prunus persica L.) fruit from Pakistan, Molecules 17 (2012) 6491-6506.

[8] N. Dhingra, Sharma R., Kar A., Towards further understanding on the antioxidative activities of Prunus persica fruit: A comparative study with four different fractions, Spectrochim. Acta. A. 132 (2014) 582-587.

[9] Demir N., Yildiz O., Alpaslan M., Hayaloglu A.A.,Evaluation of volatiles, phenolic compounds and antioxidant activities of rose hip (Rosa L.) fruits in Turkey, Lebensm.-Wiss. Technol. 57 (2014) 126-133.

[10] Tsantili E., Shin Y., Nock J.F., Watkins C.B., Antioxidant concentrations during chilling injury development in peaches, Postharvest. Biol. Technol. 57 (2010) 27-34.

[11] http://www.whfoods.com/genpage.php?tname=foodspice $\&$ $\mathrm{dbid}=35$.

[12] Ertekina C., Gozlekcib S., Kabasa O., Sonmezc S., Akinci I., Some physical, pomological and nutritional properties of two plum (Prunus domestica L.) cultivars, J. Food Eng. 75 (2006) 4, 508-514.

[13] Roomi A.B., Al-Salih R.M.H., Kredy H.M., Study of polyphenolic extracts of Prunus domestica L. Wall nuts as hypolipidemic agents, Int. J. Curr. Microbiol. App. Sci. 2 (2013) 154-171. 
[14] YIldiz O., Alpaslan M., Properties of rose hip marmalades, Food Technol. Biotechnol. 50 (2012) 98-106.

[15] Lucas E., Hammond L., Mocanu V., Arquitt A., Trolinger A., Khalil D., Smith B., Soung D., Daggy B., Arjmandi B., Daily consumption of dried plum by postmenopausal women does not cause undesirable changes in bowel function, J. Appl. Res. 4 (2004) 37-43.

[16] Crisosto C.H., Garner D., Crisosto G.M., Bowerman E., Increasing 'Blackamber' plum (Prunus salicina Lindell) consumer acceptance, Postharvest. Biol. Technol. 34 (2004) 237-244.

[17] Vizzotio M., Cisneros-Zevallos L., Byrne D.H., Large variation found in the phytochemical and antioxidant activity of peach and plum germplasm, Amer. Soc. Hart. Sci. 132 (2007) 334-340.

[18] Kim D.O., Jeong S.W., Lee C.Y., Antioxidant capacity of phenolic phytochemicals from various cultivars of plums, Food Chem. 81 (2003) 321-326.

[19] Tomas-Barbenin F.A., Gil M.1., Cremin P., Waterhouse A.L., Hess Pierce B., Kader A.A., HPLC-DAD-ESIMS analysis of phenolic compounds in nectarines, peaches, and plums, J. Agric. Food. Chem. 49 (2001) 4748-4760.

[20] Gil M., Tomas-Barberan F., Hess-Pierce B., Kader A., Antioxidant capacities, phenolic compounds, carotenoids, and vitamin A contents of nectarine, peach, and plum cultivars from California, J. Agric. Food. Chem. 50 (2002) 4976-4982.

[21] Cantin C.M., Moreno M.A., Gogorcena Y., Evaluation of the antioxidant capacity, phenolic compounds, and vitamin c content of different peach and nectarine [Prunus persica (L.) Batsch] breeding progenies, J. Agric. Food. Chem. 57 (2009) 4586-4592.

[22] Petridis A., Koukourikou M., Sotiropoulos T., Stylianidis D., Antioxidant activity of fruits produced in Northern Greece, Hortscience. 45 (2010) 1341-1344.

[23] Romandini S., Tulipani S., Mezzetti B., Capocasa F., Bompadre S., Gracia S., Battino M., Preliminary survey on nutritional and commercial features of peaches from Emilia Romagna: Antioxidant properties as a possible novel quality parameter, Ital. J. Food Sci. 20 (2008) 543-551.

[24] Abidi W., Jimenez S., Angeles Moreno M., Gogorcena Y., Evaluation of antioxidant compounds and total sugar content in a nectarine [Prunus persica (L.) Batsch] progeny, Int. J. Mol. Sci. 12 (2011) 6919-6935.

[25] Karav S., Eksi A., Antioxidant capacity and total phenolic contents of peach and apricot cultivars harvested from different regions of Turkey, Int. J. Food Sci. Nutr. 1 (2012) 13-17.

[26] Giuffrida D., Torre G., Dugo P., Dugo G., Determination of the carotenoid profile in peach fruits, juice and jam, Fruits 68 (2013) $39-44$.

[27] Dimitrijevic M., Stankov Jovanovic V., Cvetkovic J., MihajilovKrstev T., Stojanovic G., Mitica V., Screening of antioxidant, antimicrobial and antiradical activities of twelve selected Serbian wild mushrooms, Anal. Methods 7 (2015) 4181-4191.

[28] Rakotobe M., Menut C., Andrianoelisoa H.S., Rahajanirina V., Collas de Chatelperron P., Roger E., Danthu P., The bark essential oil composition and chemotaxonomical appraisal of Cedrelopsis grevei H. Baillon from Madagascar, Nat. Prod. Commun. 3 (2008) 1145-1150.

[29] Kim D.-O., Kim Y.J., Heo H.J., Freer J., Padilla-Zakour O.I., Lee C.Y., Phenolics and antioxidant capacity in selected New York State plums, N. Y. Fruit. Q. 12 (2004) 9-12.
[30] Horsakova J., Sochor J., Krska B., Assessment of antioxidant activity and total polyphenolic compounds of peach varieties infected with the plum pox virus, Acta. U. Agr. Fac. Silvi. 61 (2013) 1693-1701.

[31] Rickman J.C., Barrett D.M., Bruhn C.M., Nutritional comparison of fresh, frozen and canned fruits and vegetables. Part 1. Vitamins C and B and phenolic compounds, J. Sci. Food. Agric. 87 (2007) 930-944.

[32] Oliveira A., Pintado M., Almeida D.P.F., Phytochemical composition and antioxidant activity of peach as affected by pasteurization and storage duration, LWT-Food Sci. Technol. 49 (2012) 202-207.

[33] Fu L., Xu B.-T., Xu X.-R., Gan R.-Y., Zhang Y., Xia E.-Q., Li H.-B., Antioxidant capacities and total phenolic contents of 62 fruits, Food Chem. 129 (2011) 345-350.

[34] [Dragovic-Uzelac V., Bursac Kovacevic D., Levaj B., Pedisic S., Mezak M., Tomljenovic A., Polyphenols and antioxidant capacity in fruits and vegetables common in the Croatian diet, Agricu. Conspec. Sci. 74 (2009) 175-179.

[35] Kwon G.-M., Kim J.-W., Youn K.S., Effect of different pretreatments on the physicochemical and antioxidant activities of cold-vacuum dried peaches, Korean J. Food Sci. Technol. 45 (2013) 466-472.

[36] Rop O., Jurikova T., Mlcek J., Kramarova D., Sengee Z., Antioxidant activity and selected nutritional values of plums (Prunus domestica L.) typical of the White Carpathian Mountains, Sci. Hortic. 122 (2009) 545-549.

[37] Los J., Wilska J.J., Pawlak M., Polyphenolic compounds of plums (Prunus domestica), Pol. J. Food. Nutr. Sci. 50 (2000) 35-38.

[38] Chun O.K., Kim D.O., Consideration on equivalent chemicals in total phenolic assay of chlorogenic acid-rich plums, Food. Res. Int. 37 (2004) 337-342.

[39] Morabbi N.A., Jamei R., Free radical scavenging capacity and antioxidant activity of methanolic and ethanolic extracts of plum (Prunus domestica L.) in both fresh and dried samples, Avicenna. J. Phytomed. 4 (2014) 343-353.

[40] Siddiq M., Plums and prunes, in Hui Y.H. (Ed.), Handbook of fruits and fruit processing. Blackwell Publishing Professional, Lowa, 2006.

[41] Siddiq M., Sinha N.K., Cash J.N., Characterization of polyphenoloxidase from Stanley plums, J. Food. Sci. 57 (1992) 1177-1179.

[42] Santos C.M., Abreu C.M.P., Freire J.M., Correa A.D., Antioxidant activity of fruits of four peach cultivars, Rev. Bras. Frutic. 35 (2013) 339-344.

[43] Kim S.N., Kim M.R., Cho S.M., Kim S.Y., Kim J.B., Cho Y.S., Antioxidant +- activities and determination of phenolic compounds isolated from oriental plums (Soldam, Oishiwase and Formosa), Nutr. Res. Pract. 6 (2012) 277-285.

[44] Cevallos-Casals B.A., Byrne D., Okie W.R., Cisneros-Zevallos L., Selecting new peach and plum genotypes rich in phenolics compounds and enhanced functional properties, Food. Chem. 96 (2006) 273-280.

[45] Tavarini S., Degl'Innocenti E., Remorini D., Massai R., Guidi L., Preliminary characterisation of peach cultivars for their antioxidant capacity, Int. J. Food. Sci. Tech. 43 (2008) 810-815. 
[46] Imeh U., Khokhar S., Distribution of conjugated and free phenols in fruits: antioxidant activity and cultivar variations, J. Agric. Food Chem. 50 (2002) 6301-6306.

[47] Stacewicz-Sapuntzakis M., Bowen P.E., Hussain E.A., Damayanti-Wood B.I., Farnsworth N.R., Chemical composition and potential health effects of prunes: a functional food? Crit. Rev. Food Sci. 41 (2001) 251-286.

[48] Thaipong K., Boonprakob U., Crosby K., Cisneros-Zevallos L., Hawkins Byrne D., Comparison of ABTS, DPPH, FRAP, and ORAC assays for estimating antioxidant activity from guava fruit extracts, J. Food Compos. Anal. 19 (2006) 669-675.

[49] Prior R.L., Wu X., Schaich K., Standardized methods for the determination of antioxidant capacity and phenolics in foods and dietary supplements, J. Agric. Food Chem. 53 (2005) 429-4302.

[50] Tabart, J., Kevers, C., Pincemail, J., Defraigne, J.O., Dommes, J., Comparative antioxidant capacities of phenolic compounds measured by various tests, Food Chem.113 (2009) 1226-1233.
[51] Huang D., Ou B., Prior R.L., The chemistry behind antioxidant capacity assays, J. Agric. Food Chem. 53 (2005)1841-1856.

[52] Antolovich M., Prenzler P.D., Patsalides E., McDonald S., Robards K., Methods for testing antioxidant activity, Analyst. 127 (2002) 183-198.

[53] Badarinath A.V., Mallikarjuna RAo K., Madhu Sudhana Chetty C., Ramkanth S., Rajan T.V.S, Gnanaprakash K., A review on in-vitro antioxidant methods: comparisions, correlations and considerations, Int. J. PharmTech. Res. 2 (2010) 1276-1285.

[54] Yildiz O., Physicochemical and sensory properties of mulberry products: Gümüžhane pestil and köme, Turk. J. Agric. For. 37 (2013) 762-771.

[55] Mitic V., Stankov Jovanovic V., Dimitrijevic M., Cvetkovic J., Simonovic S., Nikolic Mandic S., Chemometric analysis of antioxidant activity and anthocyanin content of selected wild and cultivated small fruit from Serbia, Fruits 69 (2014) 413-422.

Cite this article as: Violeta Mitic, Marija Ilic, Marija Dimitrijevic, Jelena Cvetkovic, Slobodan Ciric, Vesna Stankov Jovanovic. Chemometric characterization of peach, nectarine and plum cultivars according to fruit phenolic content and antioxidant activity. Fruits 71 (2016) $57-66$. 